Tropical Journal of Pharmaceutical Research November 2016; 15 (11): 2391-2397

ISSN: $1596-5996$ (print); 1596-9827 (electronic)

(C) Pharmacotherapy Group, Faculty of Pharmacy, University of Benin, Benin City, 300001 Nigeria.

All rights reserved.

Available online at http://www.tjpr.org

Original Research Article

http://dx.doi.org/10.4314/tjpr.v15i11.13

\title{
Anti-thrombotic and anti-tumor effect of water extract of caulis of Sargentodoxa cuneata (Oliv) Rehd et Wils (Lardizabalaceae) in animal models
}

\author{
Hong Chen ${ }^{1 *}$, Xue-mei Wan ${ }^{2}$, Xue-lei Zhou ${ }^{3}$ \\ ${ }^{1}$ Oncology Department of Traditional Chinese Medicine, Chongqing Cancer Institute (Chongqing Cancer Hospital), Chongqing, \\ 400030, ${ }^{2}$ Infectious Disease Department, ${ }^{3}$ The Spleen and Stomach Diseases Department, Teaching Hospital of Chengdu \\ University of Traditional Chinese Medicine, Chengdu, 610075, PR China
}

*For correspondence: Email: woshichenh2007@163.com; Tel: +86-023-65311341

\begin{abstract}
Purpose: To investigate the anti-thrombosis and anti-tumor effect of the water extract of the caulis of Sargentodoxa cuneata (Oliv.) Rehd. et Wils. (WCSW) in rat and mouse models.

Methods: WCSW extract was prepared and the main constituents were determined by high pressure liquid chromatography (HPLC). The acute toxicity of the extract was determined in mice. Platelet aggregation in rat platelet-rich plasma (PRP) was examined to evaluate the effect of the extract on platelet function. Thereafter, the cytotoxic activity of WCSW on HL60, A549, S180 and H22 cells was determined by 3-(4,5-Dimethylthiazol-2-yl)-2,5-diphenyltetrazolium bromide (MTT) assay. In vivo antitumor effect of WCSW was further evaluated on $\mathrm{H} 22$ cells transplanted in mice, while the expression of caspase-3, caspase-9, Bcl-2 and Bax proteins were assayed by Western blot analysis.

Results: Protocatechuic acid, rhodiola glucoside and chlorogenic acid were identified as the main constituents of WCSW. Platelet aggregation was significantly inhibited by treatment with the extract at concentrations of 1, 5 and $10 \mathrm{mg} / \mathrm{mL}$. WCSW also showed significant inhibitory effect on HL60, A549, S180 and H22 cells in vitro with half maximal inhibitory concentration (IC $C_{50}$ value of 321.9, 285.0, 130.3 and $76.1 \mu \mathrm{g} / \mathrm{mL}$, respectively. Furthermore, WCSW exhibited obvious anti-tumor effect on H22 transplanted tumor in vivo. After treatment with WCSW, caspase-3, caspase-9 and Bax were significantly $(p<0.05)$ up-regulated, whereas Bcl-2 was significantly $(p<0.05)$ down-regulated in the tumor tissues.

Conclusion: WCSW possesses significant antithrombosis and anti-tumor effect, and therefore, has the potentials to be developed into effective drugs for clinical treatment of cancer and thrombosis diseases.
\end{abstract}

Keywords: Sargentodoxa cuneata, Anti-thrombosis, Anti-tumor, Platelet aggregation, Apoptosis, Caspase, Protocatechuic acid, Rhodiola glucoside, Chlorogenic acid

Tropical Journal of Pharmaceutical Research is indexed by Science Citation Index (SciSearch), Scopus, International Pharmaceutical Abstract, Chemical Abstracts, Embase, Index Copernicus, EBSCO, African Index Medicus, JournalSeek, Journal Citation Reports/Science Edition, Directory of Open Access Journals (DOAJ), African Journal Online, Bioline International, Open-J-Gate and Pharmacy Abstracts

\section{INTRODUCTION}

Thrombus formation is a pivotal event involved in the pathogenesis of cardiovascular disease, and platelets are critical in all phases of thrombus formation [1]. Antithrombotic drugs, such as adenosine diphosphate (ADP) receptor blockers, acetylsalicylic acid (aspirin), and glycoprotein (GP) Ilb/llla antagonists are used to prevent cardiovascular disease [2]. However, these drugs can have systemic hemorrhagic side effects $[3,4]$. Cancer is a very serious medical condition worldwide. The current medical treatments for cancer including chemotherapy and 
radiotherapy, often have serious side effects $[5,6]$. Therefore, it is very important to develop much safer antithrombotic and anti-tumor agents with fewer side effects.

Sargentodoxa cuneata (Oliv.) Rehd. et Wils. (SRW), belonging to Lardizabalaceae, is a common Chinese medicinal plant which is distributed in South, East, Central and Southwest China [7]. The caulis of SRW is used in China for treating acute appendicitis, abdominal pain, rheumatic arthritis, trauma, amenorrhea and dysmenorrhea [8]. Several kinds of compounds such as lignans, triterpenes, anthraquinones, phenolic acids, and phenylpropanoids have been previously isolated from SRW $[7,9]$. However, to the best of our knowledge, only a few researches reported the pharmacological activities of SRW. The present research was aimed to investigate the antithrombosis and anti-tumor effect of water extract of caulis of SRW (WCSW), which may encourage the development and application of this drug.

\section{EXPERIMENTAL}

\section{Chemicals and reagents}

Adenosine 5'-diphosphate (ADP), collagen, acetylsalicylic acid (AA) and 3-(4,5Dimethylthiazol-2-yl)-2,5-diphenyltetrazolium bromide (MTT) were purchased from Sigma (St. Louis, MO, USA). Protocatechuic acid, Rhodiola glucoside, and Chlorogenic acid standards were purchased from National Institute for Food and Drug Control (Beijing, China). 5-Fluorouracil (5FU) was obtained from Sinopharm Chemical Reagent Co., Ltd. (Shanghai, China). Caspase-3, caspase-9, Bcl-2, Bax, and $\beta$-actin antibodies were purchased from Beyotime Institute of Biotechnology (Nanjin, China). All the other chemicals used were of analytical grade.

\section{Preparation of WCSW}

Dried crude caulis of SRW was purchased from Chengdu Hehuachi Chinese Herbal Medicine Market (Chengdu, China) in August, 2015, and identified by the Oncology Department of Traditional Chinese Medicine (Chongqing Cancer Research Institute, Chongqing, China). A voucher specimen (no. HM2015-0807) was deposited in the laboratory herbarium of Chongqing Cancer Research Institute. The caulis of SRW was powdered and refluxed two times for $2 \mathrm{~h}$ each time with distilled water. The filtrates were concentrated under reduced pressure at 40
${ }^{\circ} \mathrm{C}$ and the final yield of the extract (WCSW) was about $12.7 \%(w / w)$.

\section{Determination of major constituents of WCSW}

An HPLC system consisting of Waters 2695 HPLC and UV detector (Waters, USA) was used to analyze the constituents in WCSW. The components of WCSW were isolated on a Diamonsil C18 $(250 \times 4.6 \mathrm{~mm}$, with $5 \mu \mathrm{m}$ particle size) column (Dikma, Beijing). The column temperature was controlled at $30{ }^{\circ} \mathrm{C}$ and the UV detector was set at $280 \mathrm{~nm}$. The gradient elution system was composed of acetonitrile as solvent $A$ and $0.05 \%$ solution of phosphoric acid in water as solvent $\mathrm{B}$, and was set as follows: $0-10$ $\min , 95 \%$ B; 10 - $35 \min , 95 \%$ - 84\% B; 35 - 50 $\min , 84 \%-75 \%$ B; $50-60 \min , 75 \%-55 \%$ B. The flow rate was $1.0 \mathrm{~mL} / \mathrm{min}$.

\section{Animals}

ICR mice $(20 \pm 2 \mathrm{~g})$ and Sprague-Dawley (SD) rats $(210 \pm 10 \mathrm{~g})$ were purchased from Dashuo experimental animal Co. Ltd. (Chengdu, China). Animals were maintained at $23 \pm 2{ }^{\circ} \mathrm{C}$ and $55 \pm 5$ $\%$ humidity under a 12-h light/12-h dark cycle and free access to food and water. All the animal treatments were strictly in accordance with Directive 2010/63/EU on the Handling of Animals Used for Scientific Purposes [10]. The experimental procedures were approved by the Animal Care and Use Committee of Chongqing Cancer Research Institute (approval no. 201509$\mathrm{N}-12)$.

\section{Cell culture}

The cell lines of A549, HL60, S180 and H22 were cultured in RPMI medium supplemented with $10 \%$ fetal bovine serum and antibiotics (100 $\mathrm{U} / \mathrm{mL}$ penicillin and $100 \mu \mathrm{g} / \mathrm{mL}$ streptomycin), and incubated at $37{ }^{\circ} \mathrm{C}$ in the presence of $5 \%$ $\mathrm{CO}_{2}$.

\section{Acute toxicity test}

Acute toxicity of WCSW on mice was carried out according to a previous report [11]. Mice were divided into six groups $(n=10)$ and fasted for $12 \mathrm{~h}$ prior to the experiment with free access to water. The animals were administered orally with a single dose of WCSW $(10,100,500,1000$ and $2000 \mathrm{mg} / \mathrm{kg}$ ), or distilled water for the control group. After that, the mice were observed for clinical signs and mortality at $0.5,1,2,4$, and $6 \mathrm{~h}$ after dosing and twice a day thereafter for 14 days. 


\section{Assessment of platelet aggregation}

Platelet aggregation was determined using the turbidimetric method reported by Xin et al [12]. $S D$ rats were lightly anesthetized with diethyl ether. Blood was drawn from the abdominal aorta and collected into blood collection tube containing $3.8 \%$ sodium citrate $(1: 9, \mathrm{v} / \mathrm{v})$. Platelet-rich plasma (PRP) was prepared by centrifuged at $800 \mathrm{rpm}$ for $10 \mathrm{~min}$. Platelet-poor plasma (PPP) was obtained by further centrifuged at $3000 \mathrm{rpm}$ for $10 \mathrm{~min}$. The PRP was diluted with PPP to make platelet concentration of $5 \times 10^{8} / \mathrm{mL}$.

For the aggregation experiment, the diluted PRP was incubated at $37^{\circ} \mathrm{C}$ for 5 min with different concentrations of WCSW $(1,5$ and $10 \mathrm{mg} / \mathrm{mL})$. Subsequently, arachidonic acid $(0.5 \mathrm{mmol} / \mathrm{L})$, ADP $(5 \mu \mathrm{mol} / \mathrm{L})$, or collagen $(3.2 \mu \mathrm{g} / \mathrm{mL})$ was added to induce platelet aggregation. Aspirin (25 $\mu \mathrm{g} / \mathrm{mL}$ ) was used as positive control. The changes in light transmission were recorded for 5 $\min$.

\section{MTT assay}

Cells were seeded into 96 -well plates at a concentration of $1 \times 10^{5} / 0.1 \mathrm{~mL}$ in the presence of WCSW $(10-640 \mu \mathrm{g} / \mathrm{mL})$ for $48 \mathrm{~h}$. The growth inhibitory effect of the cells was determined by MTT assay. Briefly, each well was added $20 \mu \mathrm{L}$ MTT $(5 \mathrm{mg} / \mathrm{mL})$ and incubated for another $4 \mathrm{~h}$. Then the culture medium was removed, and 150 $\mu \mathrm{L}$ DMSO was added to each well. Absorbance was detected by a microplate reader at $570 \mathrm{~nm}$. Inhibition (I) of cell proliferation was calculated by Eq 1.

$I(\%)=\{(\mathrm{Ac}-\mathrm{At}) / \mathrm{Ac}\} 100$

where Ac and At are the absorbance of control and treatment samples respectively.

\section{In vivo antitumor experiment}

H22 tumor cell suspension $\left(2 \times 10^{6}\right.$ cells/mouse, $0.2 \mathrm{~mL}$ ) was subcutaneously injected into the right armpits of ICR mice to establish the animal model [13]. The mice were randomly divided into five groups $(n=10)$ : the model control group, the positive group and three WCSW-treated groups $(20,40$ and $80 \mathrm{mg} / \mathrm{kg})$ by intragastric administration (ig). Control group was treated with normal saline $\{20 \mathrm{~mL} / \mathrm{kg}$, intraperitoneally (ip)\} while the positive group was treated with 5FU (20 mg/kg, ip). All the mice were sacrificed after treatment for 14 days, and the whole bodies and the segregated tumor of the mice were weighed immediately.

\section{Western blot analysis}

Total proteins were extracted from the tumor tissues. Protein samples $(50 \mu \mathrm{g})$ were separated using sodium dodecyl sulfate polyacrylamide gel electrophoresis (SDS/PAGE). Thereafter, the separated proteins were transferred to a polyvinylidene difluoride (PVDF) membrane and probed with different primary antibodies targeting caspase-3, caspase-9, Bax, or Bcl-2 overnight at $4{ }^{\circ} \mathrm{C}$. After washing with Tris buffered saline three times, the membrane was incubated with secondary antibodies. The proteins were detected using chemiluminescence peroxidase reagents. Antibody directed against $\beta$-actin was used to measure protein loading.

\section{Statistical analysis}

Data are expressed as mean \pm standard deviation (SD). One-way ANOVA followed by ttest was performed on the data using SPSS software (SPSS for Windows 18.0, SPSS Inc, USA) to determine differences between the treated and control groups. $P<0.05$ was considered statistically significant.

\section{RESULTS}

\section{Main constituents of WCSW}

In order to detect the constituents in WCSW, HPLC was performed in the present study. As shown in Figure 1, WCSW was well separated under the experimental conditions. Three constituents including protocatechuic acid, rhodiola glucoside and chlorogenic acid were identified by comparing their retention times and UV spectra with the corresponding reference standards.

\section{Acute toxicity}

Acute toxicity of WCSW was carried out in mice by oral administration. As a result, there was no death and significant modification in the general behavior of the animals after 14 days at all the administered doses of WCSW. Hence, WCSW was apparently safe when administered orally to mice under the studied doses.

\section{Effect of WCSW on platelet aggregation in vitro}

The effect on ADP, AA and collagen induced platelet aggregation in rat PRP were examined to evaluate the effect of WCSW on platelet function. Platelet aggregations induced by collagen and 


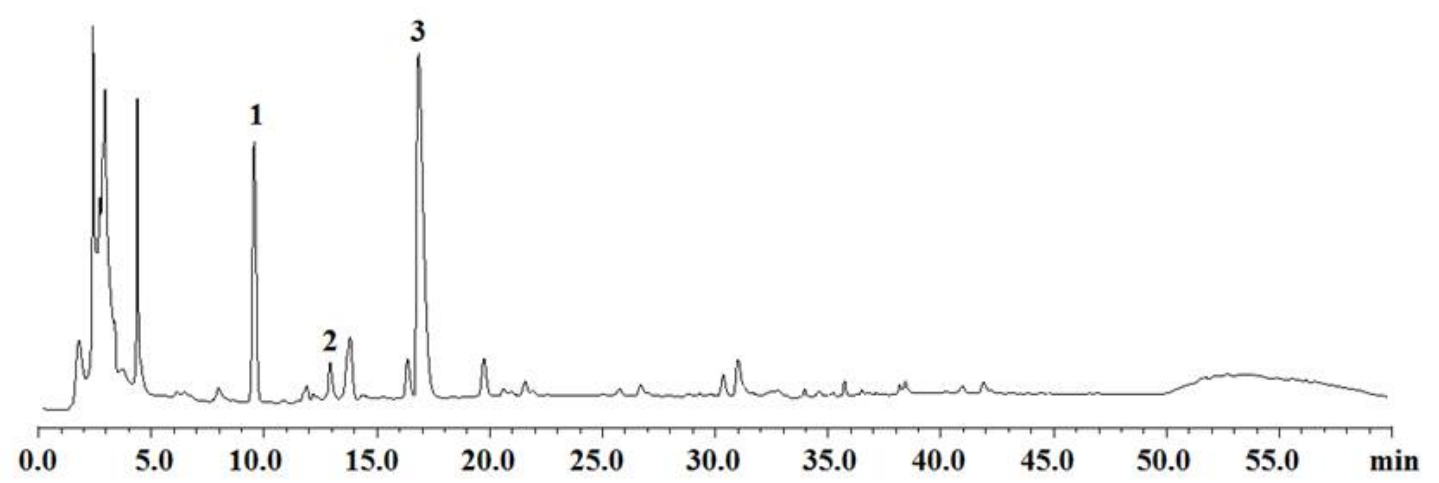

Figure 1: HPLC chromatogram for WCSW. (1) protocatechuic acid, (2) rhodiola glucoside, (3) chlorogenic acid
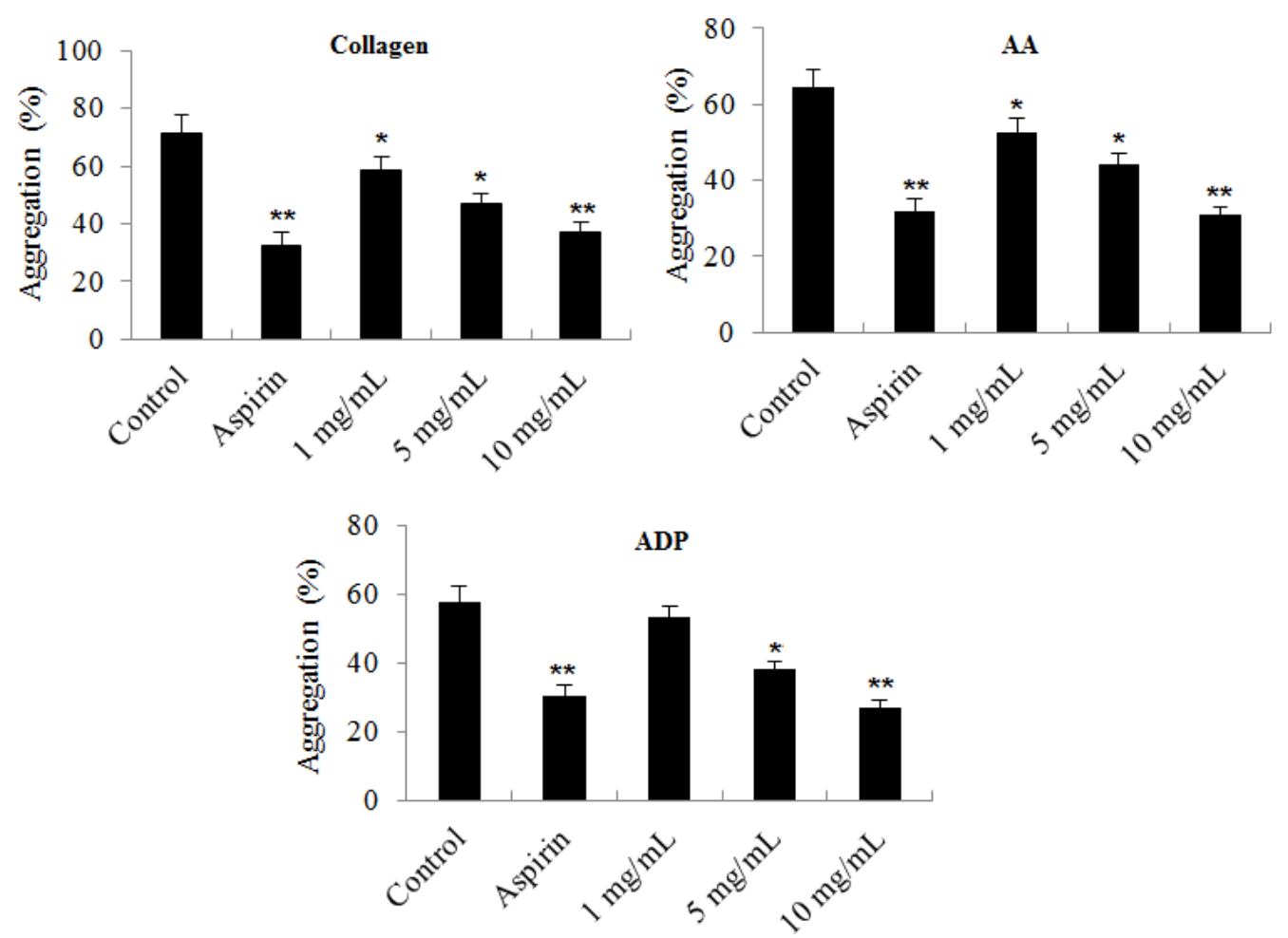

Figure 2: The effect of WCSW on platelet aggregation. ${ }^{*} p<0.05$ compared with the control group. ${ }^{* *} p<0.01$ compared with control group

AA were significantly inhibited by treating with WCSW at the concentrations of 1,5 , and 10 $\mathrm{mg} / \mathrm{mL}(p<0.05, p<0.05$ and $p<0.01$, respectively) in a concentration-dependent manner (Figure 2). Furthermore, the inhibitory effect of WCSW on the platelet aggregations induced by ADP was also significant at the concentrations of 5 and $10 \mathrm{mg} / \mathrm{mL}(p<0.05$ and $p<0.01$, respectively).

\section{Cytotoxic activity of WCSW in vitro}

The proliferation of HL60, A549, S180 and H22 cells was determined to investigate the cytotoxic activities of WCSW and the cell viability was determined by the MTT assay. The results in
Figure 3 indicate WCSW exerted significant inhibitory effects on HL60, A549, S180 and H22 cells (the $I C_{50}$ values were $321.9,285.0,130.3$, and $76.1 \mu \mathrm{g} / \mathrm{mL}$, respectively) in a concentrationdependent manner. Thus, H22 cells were the most sensitive in responding to WCSW administration.

\section{Effect of WCSW on H22 transplanted tumor in vivo}

Anti-tumor activity of WCSW in $\mathrm{H} 22$ cell transplanted mice was evaluated based on its favorable in vitro cytotoxic activity against hepatic carcinoma cells. As shown in Figure 4, the average tumor weight of the mice in WCSW 


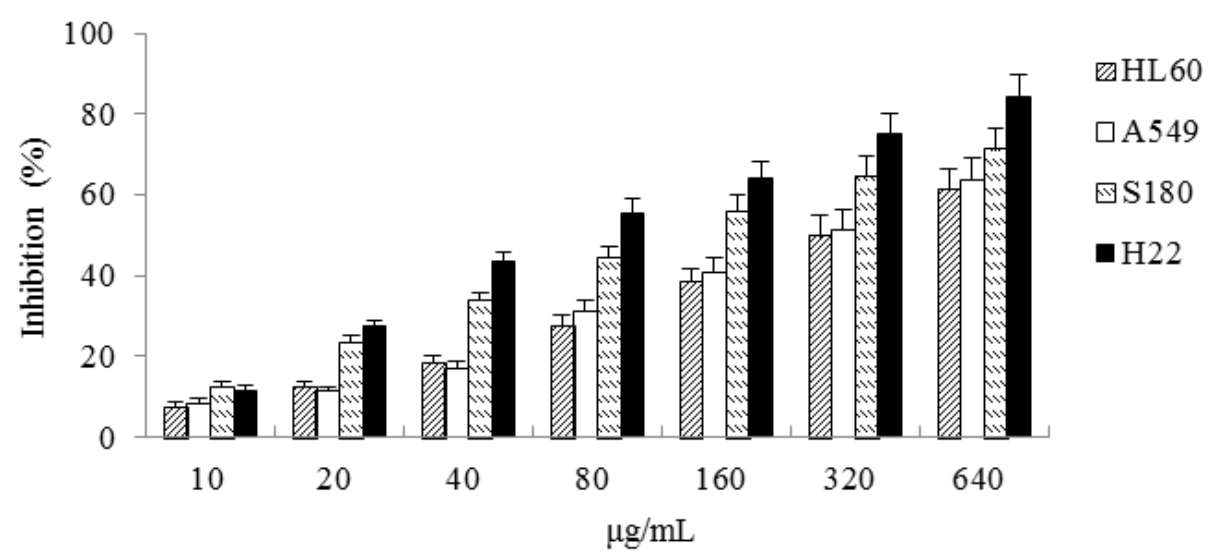

Figure 3: Cytotoxic activities of WCSW against HL60, A549, S180 and H22 cells

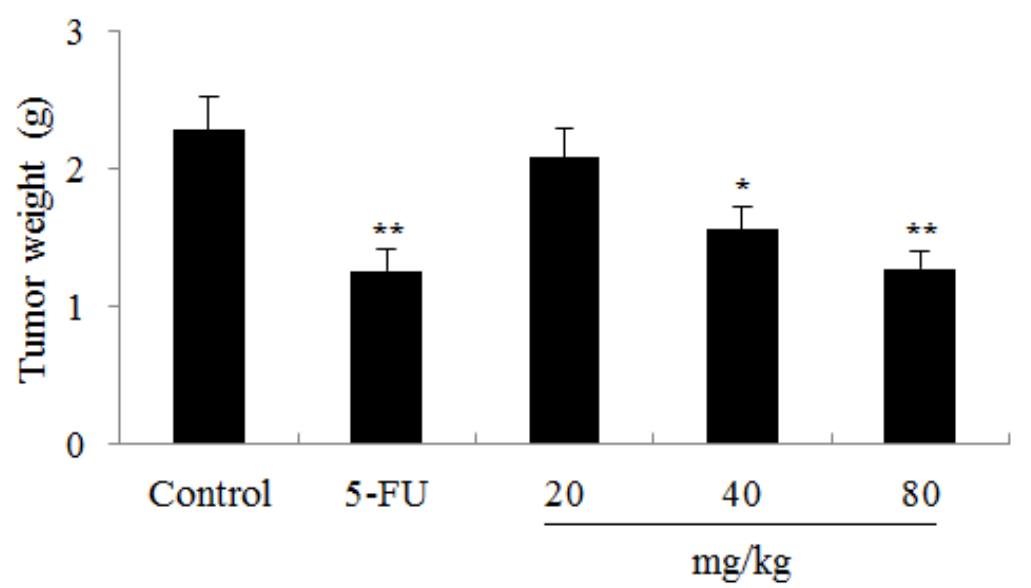

Figure 4: Anti-tumor effect of WCSW on $\mathrm{H} 22$ transplanted tumor in vivo. ${ }^{*} p<0.05$ compared with the control group; ${ }^{* *} p<0.01$ compared with control group.
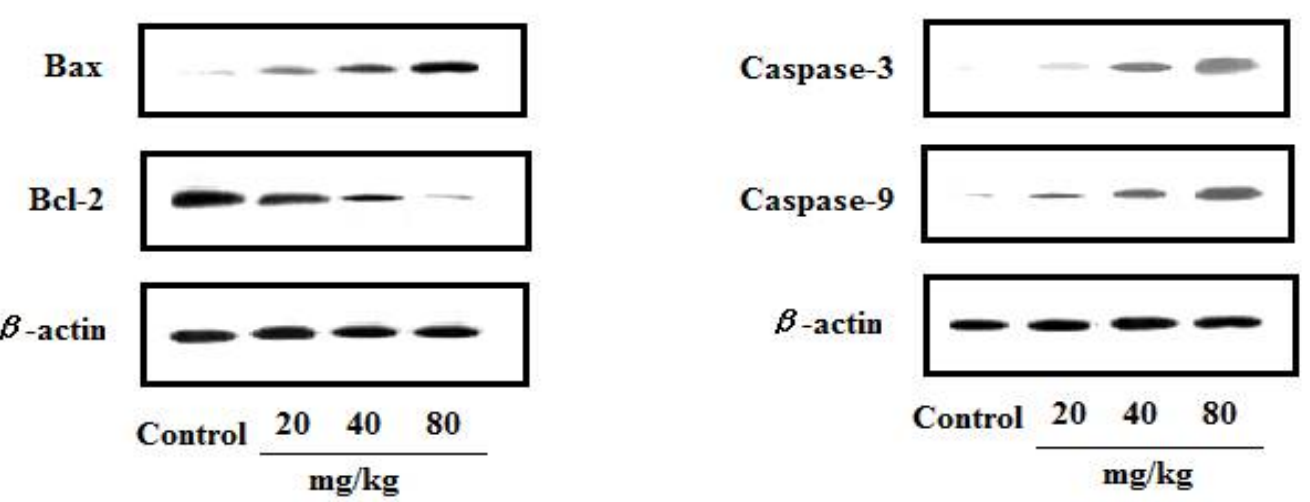

Figure 5: Effect of WCSW on expressions of apoptosis-related proteins caspase-3, caspase-9, Bcl-2 and Bax

treated groups (40 and $80 \mathrm{mg} / \mathrm{kg})$ were significantly lower than that of the control group, indicating that WCSW had anti-tumor effect on $\mathrm{H} 22$ transplanted tumor in vivo.

\section{WCSW induced cell apoptosis in $\mathrm{H} 22$ transplanted tumor}

To determine whether WCSW treatment induced cell apoptosis in transplanted tumors, the protein expressions of caspase- 3 , caspase- $9, \mathrm{Bcl}-2$ and Bax were assayed by western blot analysis. $\beta$ actin was used as internal control to ensure that equal amount of proteins were loaded in each lane. From the results in Figure 5, the expressions of caspase-3, caspase-9 and Bax proteins were significantly up-regulated, whereas the expression $\mathrm{Bcl}-2$ was significantly downregulated in the tumor tissues of the mice treated

Trop J Pharm Res, November 2016; 15(11): 2395 
with WCSW at the doses of 20,40 and $80 \mathrm{mg} / \mathrm{kg}$ compared with the control group.

\section{DISCUSSION}

It was reported that activation and aggregation of platelets play important roles in thrombotic complications, such as myocardial infarction, acute coronary syndromes and atherosclerosis, etc. $[14,15]$. Recently, there has been increasing interest to isolate thrombolytic and antithrombotic agents from food and natural sources, which are presumed to be effective and safe [16]. In the present study, the antithrombosis effect of WCSW were studied, and it was proved to be safe by oral administration and possessed significant inhibitory effect on ADP, AA and collagen induced platelet aggregation in rat PRP. Caspases are the key proteins that regulate apoptotic response, and the activation of caspase- 3 and caspase- 9 is one of the most common involvements in the process of apoptosis in many cell types [17,18]. The mitochondrial pathway of apoptosis is regulated by the $\mathrm{Bcl}-2$ family, and $\mathrm{Bcl}-2$ and $\mathrm{Bax}$ are the two major members of $\mathrm{Bcl}-2$ family [19]. The increase in the ratio of $\mathrm{Bax} / \mathrm{Bcl}-2$ is beneficial to apoptosis [20]. Furthermore, it is well known that the caspase family plays a vital role in cells undergoing apoptosis by interfering with the Bcl2 family [21]. Thus, the expressions of caspase3 , caspase-9, $\mathrm{Bcl}-2$ and $\mathrm{Bax}$ proteins were evaluated in the present study. The results indicated that WCSW induced apoptosis in H22 tumor by shifting the $\mathrm{Bax} / \mathrm{Bcl}-2$ ratio and increasing the caspase- 9 and caspase-3 activation.

In addition, more investigations should be carried out in the future to explore the constituents regarding the antithrombotic and anti-tumor effects, and develop new drugs from WCSW.

\section{CONCLUSION}

The findings of the present study indicate that WCSW possesses significant antithrombotic effect by inhibiting platelet aggregation. The extract also exerts significant anti-tumor effect by inducing apoptosis. Thus, WCSW has potentials to be developed into and effective drug for the treatment of cancer and thrombotic diseases.

\section{DECLARATIONS}

\section{Conflict of Interest}

No conflict of interest associated with this work.

\section{Contribution of Authors}

The authors declare that this work was done by the authors named in this article and all liabilities pertaining to claims relating to the content of this article will be borne by them.

\section{Open Access}

This is an Open Access article distributed under the terms of the Creative Commons Attribution License, which permits unrestricted use, distribution, and reproduction in any medium, provided the original work is properly credited.

\section{REFERENCES}

1. Steinhubl SR, Moliterno DJ. The role of the platelet in the pathogenesis of atherothrombosis. $A m \mathrm{~J}$ Cardiovasc Drugs 2005; 5(6): 399-408.

2. Lange RA, Hillis LD. Antiplatelet therapy for ischemic heart disease. N Engl J Med 2004; 350(3): 277-280.

3. Lee JJ, Kim T, Cho WK, Ma JY. Antithrombotic and antiplatelet activities of Soshiho-tang extract. BMC Complement Altern Med 2013; 13: 137-145.

4. Serebruany VL, Malinin AI, Eisert RM, Sane DC. Risk of bleeding complications with antiplatelet agents: metaanalysis of 338,191 patients enrolled in 50 randomized controlled trials. Am J Hematol 2004; 75(1): 40-47.

5. Jiao L, Zhang X, Li B, Liu Z, Wang M, Liu S. Anti-tumour and immunomodulatory activities of oligosaccharides isolated from Panax ginseng C.A. Meyer. Int J Biol Macromol 2014; 65: 229-233.

6. Kimura K, Sakamoto Y, Fujisawa N, Uesugi S, Aburai N, Kawada M, Ohba S, Yamori T, Tsuchiya E, Koshino $H$. Cleavage mechanism and anti-tumor activity of 3,6epidioxy-1,10-bisaboladiene isolated from edible wild plants. Bioorg Med Chem 2012; 20(12): 3887-3897.

7. Zeng $X$, Wang $H$, Gong $Z$, Huang J, Pei W, Wang $X$, Zhang J, Tang $X$. Antimicrobial and cytotoxic phenolics and phenolic glycosides from Sargentodoxa cuneata. Fitoterapia 2015; 101: 153-161.

8. National Bureau of Chinese Traditional Medicine Editorial Committee. Zhong Hua Ben Cao. Shanghai Press of Science and Technology, Shanghai 1998; $p 571$.

9. Chang J, Case R. Phenolic glycosides and ionone glycoside from the stem of Sargentodoxa cuneata. Phytochem 2005; 66(23): 2752-2758.

10. European Commission [homepage on the internet]. Directive 2010/63/EU on the protection of animals used for scientific purposes [cited 2013 Jan 16]. Available from:http://ec.europa.eu/environment/chemicals/lab_ani mals/legislation_en.htm.

11. Ntchapda F, Abakar D, Kom B, Nana P, Hamadjida A, Dimo T. Acute and sub-chronic oral toxicity assessment of the aqueous extract leaves of Ficus glumosa Del. 
(Moraceae) in rodents. J Intercult Ethnopharmacol 2014; 3(4): 206-213.

12. Xin $M$, Ren L, Sun $Y$, Li HH, Guan HS, He XX, Li CX. Anticoagulant and antithrombotic activities of lowmolecular-weight propylene glycol alginate sodium sulfate (PSS). Eur J Med Chem 2016; 114: 33-40.

13. Li JT, Zhang JL, He H, Ma ZL, Nie ZK, Wang ZZ, Xu XG. Apoptosis in human hepatoma HepG2 cells induced by corn peptides and its anti-tumor efficacy in H22 tumor bearing mice. Food Chem Toxicol 2013; 51: 297-305.

14. Vande Griend JP, Saseen JJ. Combination antiplatelet agents for secondary prevention of ischemic stroke. Pharmacother 2008; 28(10): 1233-1242.

15. Lee JJ, Kim T, Cho WK, Ma JY. Antithrombotic and antiplatelet activities of Soshiho-tang extract. BMC Complement Altern Med 2013; 13: 137.

16. Choi JH, Kim DW, Park SE, Lee HJ, Kim KM, Kim KJ, Kim MK, Kim SJ, Kim S. Anti-thrombotic effect of rutin isolated from Dendropanax morbifera Leveille. J Biosci Bioeng 2015; 120(2): 181-186.

17. Ghobrial IM, Witzig TE, Adjei AA. Targeting apoptosis pathways in cancer therapy. CA Cancer J Clin 2005; 55(3):178-194.
18. Mancini $M$, Nicholson DW, Roy S, Thornberry NA, Peterson EP, Casciola-Rosen LA, Rosen $A$. The caspase-3 precursor has a cytosolic and mitochondrial distribution: implications for apoptotic signaling. J Cell Biol 1998; 140(6): 1485-1495.

19. Bruce-Keller AJ, Begley JG, Fu W, Butterfield DA, Bredesen DE, Hutchins JB, Hensley $K$, Mattson MP. $\mathrm{Bcl}-2$ protects isolated plasma and mitochondrial membranes against lipid peroxidation induced by hydrogen peroxide and amyloid beta-peptide. $J$ Neurochem 1998; 70(1): 31-39.

20. Zha $H$, Reed JC. Heterodimerization-independent functions of cell death regulatory proteins Bax and Bcl-2 in yeast and mammalian cells. J Biol Chem 1997; 272(50): 31482-31488.

21. Qi F, Li A, Zhao L, Xu H, Inagaki Y, Wang D, Cui X, Gao $B$, Kokudo N, Nakata $M$, et al. Cinobufacini, an aqueous extract from Bufo bufo gargarizans Cantor, induces apoptosis through a mitochondria-mediated pathway in human hepatocellular carcinoma cells. J Ethnopharmacol 2010; 128(3): 654-661. 